Prosiding Seminar Nasional Teknologi Informasi dan Kedirgantaraan : Transformasi Teknologi untuk Mendukung Ketahanan Nasional, Yogyakarta, 13 Desember 2018

SENATIK 2018, Vol. IV, ISBN 978-602-52742-0-6

DOI: http://dx.doi.org/10.28989/senatik.v4i0.143

\title{
PARALEL PROCESSING FOR VERTEX TRIPLE NUMBER SEARCH PROCESSES IN NOT DIFFERENT GRAPH USING SHARED MEMORY MODELS
}

Astika Ayuningtyas

Program Studi Informatika

Sekolah Tinggi Teknologi Adisutjipto

Jl. Janti, Blok-R, Lanud Adisucipto Yogyakarta

Email : astika@stta.ac.id

\begin{abstract}
Parallel processing is an effective strategy for describing large problems in smaller problems, in which computing techniques use two or more computers to perform a task simultaneously by optimizing the resources of existing computer systems. This study uses parallel processing techniques, in which the object of the search is the process of finding the number of triple vertices not represented in the graph. The parallel worker process then divides the workload into each process and distributes it to other threads in the system to solve a problem. The model used in parallel processing is shared memory. This model optimizes the performance of threads on the processor. The experiments carried out make it possible to conclude that the processing speed of a parallel system is influenced by the number of processes and the number of vertices. On a single computer, the larger the process, the shorter the process. The same with the increase in the number of vertices resulting in a longer time.
\end{abstract}

Keyword: Parallel Processing, Shared Memory, Triple Vertex, Thread

Abstrak

Pemrosesan paralel merupakan salah satu strategi yang efisien yang memungkinkan untuk menguraikan masalah yang besar menjadi lebih kecil, dimana teknik komputasinya menggunakan dua atau lebih komputer untuk menyelesaikan suatu tugas dalam waktu yang simultan dengan cara mengoptimalkan resource pada sistem komputer yang ada. Penelitian ini memanfaatkan teknik paralel dalam pemrosesannya, dimana obyek yang akan menjadi fokus penelitian adalah proses pencarian jumlah triple vertex pada graph tidak berarah. Proses kerja dari paralel nantinya dengan membagi beban kerja perhitungan setiap proses kali dan mendistribusikannnya pada thread-thread lain yang terdapat dalam sistem untuk menyelesaikan suatu masalah. Model yang digunakan pada pemrosesan paralel ini adalah shared memory. Model ini memaksimalkan kinerja thread yang ada pada prosesor. Berdasarkan uji coba yang dilakukan dapat disimpulkan bahwa kecepatan pemrosesan suatu sistem paralel dipengaruhi oleh jumlah proses dan jumlah verteks. Pada komputer tunggal semakin besar proses maka akan menambahkan sedikit waktu pada pengerjaannya. Begitu pula dengan bertambahnya jumlah verteks mengakibatkan waktu yang diperlukan semakin besar.

Kata Kunci : Pemrosesan Paralel, Shared Memory, Triple Vertex, Thread

\section{Pendahuluan}

Pemrosesan paralel merupakan salah satu strategi yang efisien yang memungkinkan untuk menguraikan masalah yang besar menjadi lebih kecil [1], dimana teknik komputasinya menggunakan dua atau lebih komputer untuk menyelesaikan suatu tugas dalam waktu yang simultan dengan cara mengoptimalkan resource pada sistem komputer yang ada [2]. Konsep 
paralel semakin banyak pekerjaan yang bisa dilakukan secara bersamaan, maka akan semakin cepat pekerjaan tersebut terselesaikan. Seperti contoh kasus pencarian jumlah triple vertex pada graph tidak berarah yang melibatkan operasi logika di dalamnya yaitu operasi perulangan. Jika proses pencarian tersebut sudah melibatkan data yang banyak tentunya akan sangat membutuhkan waktu yang semakin panjang untuk menyelesaikan perhitungannya. Adanya konsep paralel yang membagi pekerjaan besar menjadi lebih kecil dapat menjadi salah satu solusi untuk menyelesaiakn pencarian pada kasus tersebut.

Pada model pemrosesan paralel itu sendiri ada tiga macam, yatu Network of Workstation, Shared Memory, dan Graphics Processing Unit (GPU) [3]. Dari ketiga model tersebut yang akan diimplementasikan untuk kasus perhitungan perkalian matriks dan vektor ini adalah model shared memory. Model ini memaksimalkan kinerja thread yang ada pada prosesor. Untuk penerapan dari model shared memory dalam penelitian ini adalah OpenMP. OpenMP memiliki dua tipe data yaitu data shared dan private data. Data shared dapat diakses oleh semua thread dan mempunyai nama yang sama sedangkan private data hanya dapat diakses oleh satu thread [4] [5]. Pada penelitian yang lain terkait pemrosesan parallel dan grid computing telah dibahas [6-9] digunakan sebagai bahan pertimbangan pada penlitian ini.

Penelitian ini diangkat karena peneliti tertarik dengan konsep pembagian beban pada proses yang ditawarkan di teknik komputasi paralel untuk menyelesaiakn kasus pencarian jumlah triple vertex pada graph tidak berarah. Penerapan pada model paralel ini menggunakan shared memory yaitu OpenMP. Sistem yang dibangun tidak berbasis GUI, sistem ini digunakan untuk menguji apakah konsep paralel yang diterapkan pada pencarian jumlah triple vertex di graph tidak berarah menjadi alternatif yang tepat untuk mengatasi pencarian data dengan skala yang lebih besar dibandingkan dengan menggunakan sistem secara sekuensial.

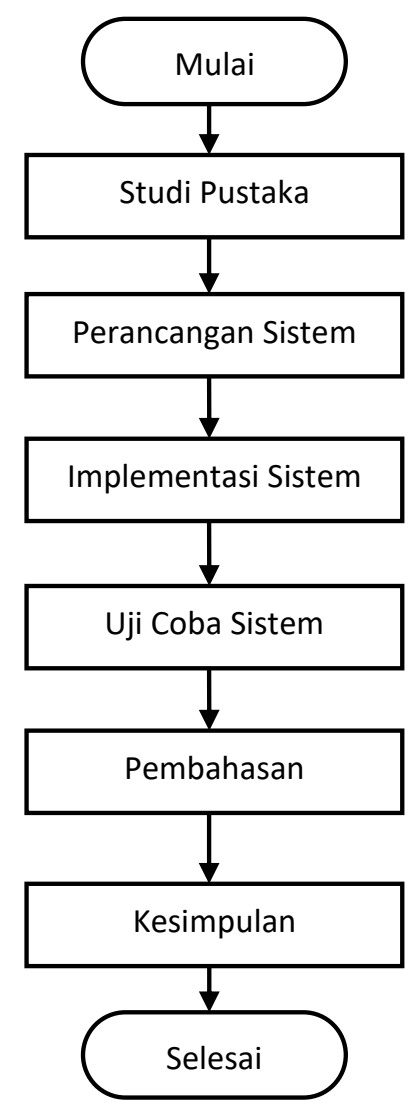

Gambar 1. Diagram Alir Metodologi Peneltian 


\section{Metodologi Penelitian}

Bagan alir menjelaskan tentang metodologi penelitian yang dilakukan dengan langkah-langkah yang terlihat pada Gambar 1.

1. Studi Pustaka

Studi pustaka untuk penelitian ini dilakukan dengan mencari, membaca dan mengumpulkan informasi, dokumen-dokumen serta teori-teori yang mendukung, seperti dari buku teks, artikel, jurnal, literatur-literatur serta browsing di internet.

2. Perancangan Sistem

Pada perancangan sistem, program akan dibuat menggunakan bahasa pemrograman $\mathrm{C}$ dengan memanfaatkan library OpenMP untuk model pemrograman paralelnya. Masukkan dari program yang dibuat ini berupa argc dan argv yang sering digunakan untuk pemrograman dengan command line interprater, dimana masukkan yang diminta adalah jumlah verteksnya. Terdapat dua model program yang digunakan untuk proses pencaian jumlah triple secara paralel, adapun model yang dirancang antara lain:

a. Proses Pencarian Triple Model Pertama

Penerapan untuk mencari triple pada matrix adjacency tidak berarah pada model pertama dengan menggunakan OpenMP (Gambar 2). Memanfaatkan penggunaan \#pragma omp for schedule untuk mengatur penjadwalan, dilakukan secara static dengan ukuran chunk yang disesuaikan dalam beberapa kali percobaan dan memanfaatkan penggunaan \#pragma omp parallel untuk mengatur penjadwalan dan membagi tugas berdasarkan thread yang ada untuk menghitung jumlah triple yang terbentuk dari verteks yang diinputkan.

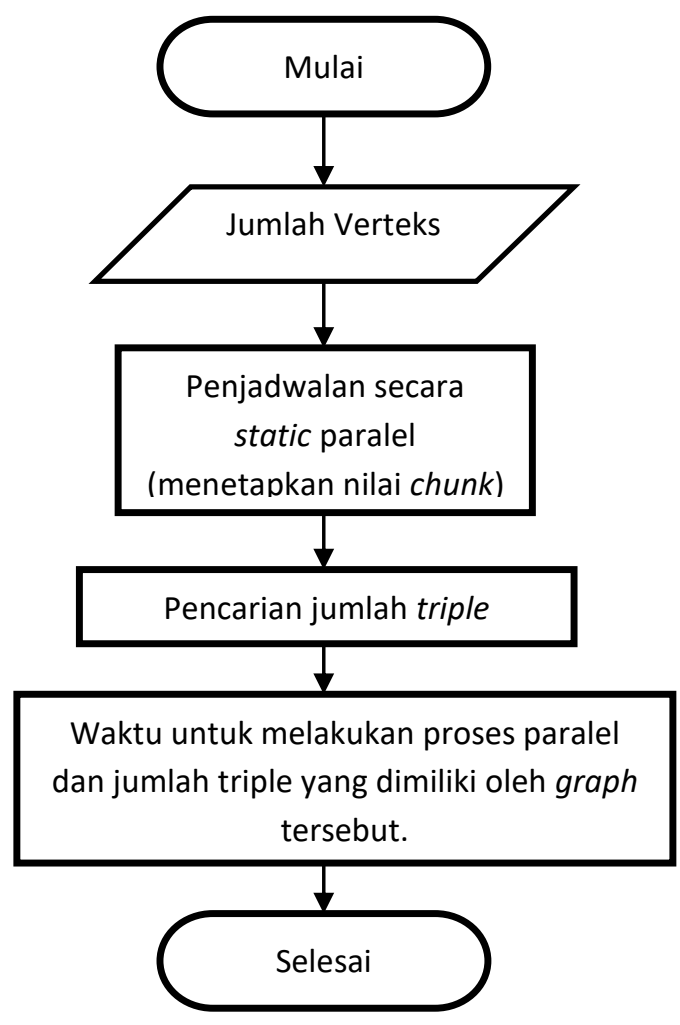

Gambar 2. Diagram Alir Proses Pencarian Triple Model Pertama 
b. Proses Pencarian Triple Model Kedua

Penerapan untuk mencari triple pada matrix adjacency tidak berarah pada model kedua dengan menggunakan OpenMP (Gambar 3). Memanfaatkan penggunaan \#pragma omp for schedule untuk mengatur penjadwalan, dilakukan secara static dengan ukuran chunk yang disesuaikan dalam beberapa kali percobaan dan memanfaatkan penggunaan \#pragma omp parallel untuk mengatur penjadwalan dengan mem-broadcast kepada semua node termasuk dirinya, kemudian masing-masing node mengerjakan proses yang sama namun dengan nilai berbeda sesuai dengan penomoran ID node yang dimiliki. Ini bertujuan untuk menghindari kesamaan nilai yang dikerjakan masing-masing node. Setelah itu, untuk mendapatkan total jumlah triple dari masing-masing node digunakan \#pragma omp critical\{ triple+=temp; .

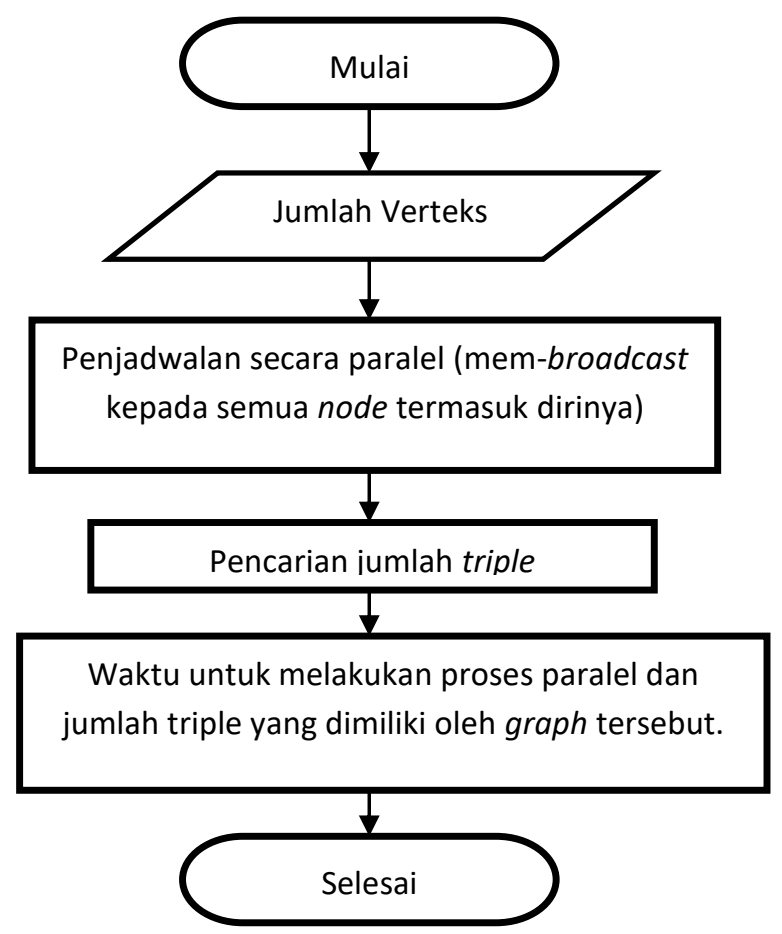

Gambar 3. Diagram Alir Proses Pencarian Triple Model Kedua

3. Implementasi Sistem

Dalam melakukan penelitian ini dibangun sebuah sistem yang menerapkan pemrosesan paralel untuk proses pencarian jumlah triple vertex pada graph tidak berarah menggunakan model shared memory, dimana sebuah sistem dibutuhkan hardware dan software yang dapat menunjang perancangan sistem.

1. Spesifikasi Hardware

Hardware (perangkat keras) merupakan perangkat secara fisik ada, dapat dilihat dan dipegang. Sistem perangkat keras secara fungsional terdiri dari input, process, output dan memory. Adapun spesifikasi hardware yang digunakan dalam pengaplikasian sistem ini, yaitu:

1. Intel (R) Core(TM) i3-5005U CPU @ 2,00GHz (4CPUs)

2. 12288 MB RAM

3. 500 GB Hardisk 
4. CD-ROM drive

5. VGA (higher resolution monitor)

6. Keyboard, Mouse Standar

7. Monitor 14.1"

2. Spesifikasi Software

Software (perangkat lunak) merupakan perangkat yang sifatnya abstrak yang berisi instruksi, program, prosedur, pengendali, pendukung dan aktivitasaktivitas pengolahan perintah pada sistem komputer. Adapun spesifikasi minumum software yang dibutuhkan dalam pengaplikasian sistem ini, yaitu:

1. Sistem Operasi Windows 10 Pro-64bit

2. Bahasa Pemrograman $\mathrm{C} / \mathrm{C}++$.

3. Pustaka OpenMP.

4. Uji Coba Sistem

Setelah program dengan dua model jadi, maka dilakukan pengujian. Pengujian dilakukan pada masing-masing model paralel yang telah sebelumnya dirancang. Data masukkan yang dilakukan untuk pengujian bervariasi dengan harapan dapat melihat seberapa efektif dan efisienkah model pemrograman paralel yang telah diterapkan untuk melakukan pencarian jumlah triple vertex pada graph yang tidak berarah.

5. Pembahasan

Hasil dari uji coba sistem yang dibangun akan diuraikan pada bagian ini untuk tujuan menganalisa hasil dari sistem yang telah diimplementasikan menggunakan model pemrograman paralel shared memory.

6. Kesimpulan

Hasil dari pembahasan akan disimpulkan hasilnya.

\section{Hasil dan Pembahasan}

Penerapan untuk mencari triple pada matrix adjacency tidak berarah dengan menggunakan OpenMP. Memanfaatkan penggunaan \#pragma omp for schedule untuk mengatur penjadwalan, dilakukan secara statis dengan ukuran chunk yang disesuaikan dalam beberapa kali percobaan menghasilkan task yang semakin kecil pada chunk yang bernilai 100 dan 10 dengan kombinasi sesuai source code yang terlihat pada Gambar 4 .

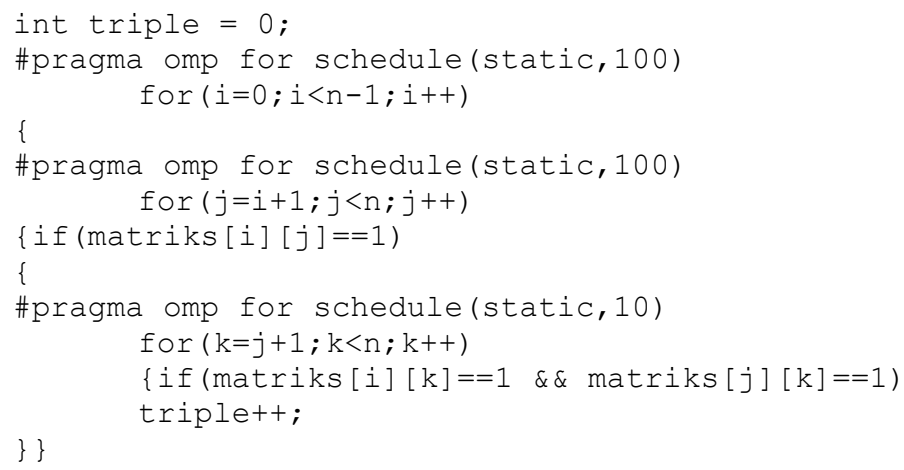

Gambar 4. Implementasi Pencarian Triple Model Pertama

Penerapan untuk mencari triple pada matrix adjacency tidak berarah dengan menggunakan OpenMP. Memanfaatkan penggunaan \#pragma omp parallel untuk mengatur 
penjadwalan dan membagi tugas berdasarkan thread yang ada untuk menghitung jumlah triple yang terbentuk dari verteks yang diinputkan (seperti yang terlihat pada Gambar 5).

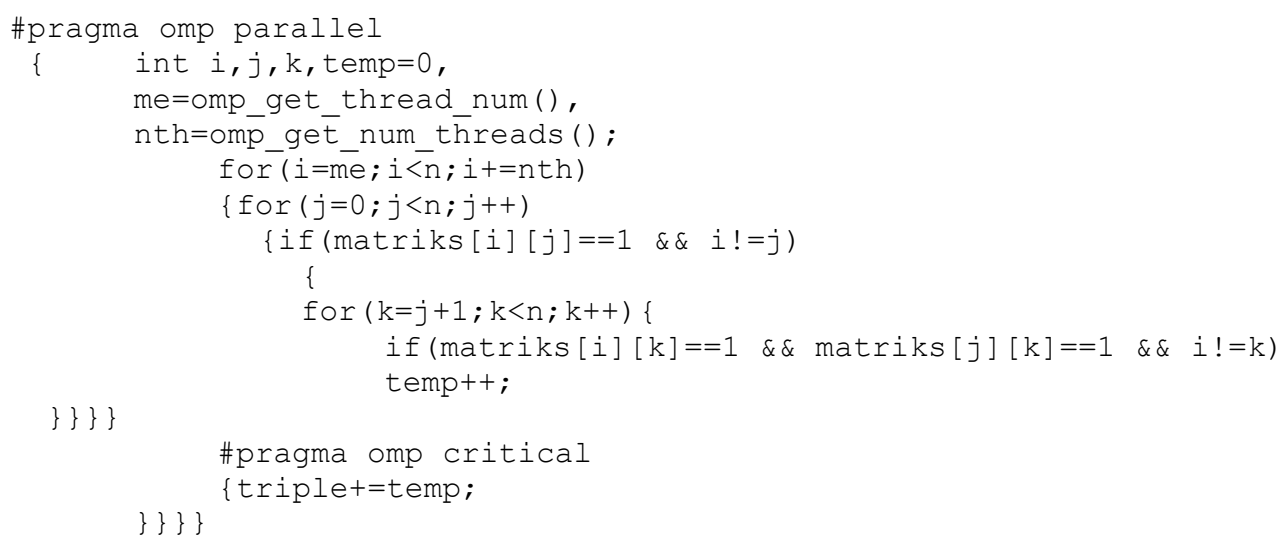

Gambar 5. Implementasi Pencarian Triple Model Kedua

Kedua model implementasi pencarian tersebut menjelaskan bahwa, untuk mencari triple diperlukan tiga buah perulangan yang berfungsi untuk melihat apakah verteks $\mathrm{i}, \mathrm{j}, \mathrm{k}$ memiliki adjacency atau tidak. Jika semua verteks tersebut memiliki adjacency, maka ketiga verteks tersebut merupakan sebuah triple.

Untuk pencarian jumlah triple dilakukan secara paralel pada model program pertama, dengan membuat loop tiga tingkat dan kemudian memparalelkan dengan cara penjadwalan secara statis dengan menetapkan nilai chunk yang telah dilakukan beberapa uji nilai untuk hasil waktu task yang semakin kecil didapatkan diproses perulangan kesatu dan kedua menggunkan ukuran chunk 100 dan di proses perulangan yang ketiga menggunkan chunk 10 . Sedangkan untuk pencarian jumlah triple dilakukan secara paralel pada model program kedua, yang pertama adalah mem-broadcast kepada semua node termasuk dirinya, kemudian masing-masing node mengerjakan proses yang sama namun dengan nilai berbeda sesuai dengan penomoran ID node yang dimiliki. Ini bertujuan untuk menghindari kesamaan nilai yang dikerjakan masing-masing node dan kemudian untuk mendapatkan total jumlah triple dari masing-masing node digunakan \#pragma omp critical \{ triple+=temp; \}

Beberapa percobaan dilakukan dengan menginputkan banyaknya verteks. Pada model kedua program dilakukan pengujian jumlah verteks yang sama untuk membandingkan waktu pengerjaannya. Hanya saja penghitungan waktu pengerjaan pada count triple di model program pertama tidak tampil, hanya di model program kedua yang berhasil tampil time dari count triple. Hasil dari beberapa percobaan dapat dilihat pada Gambar 6 dan 7.

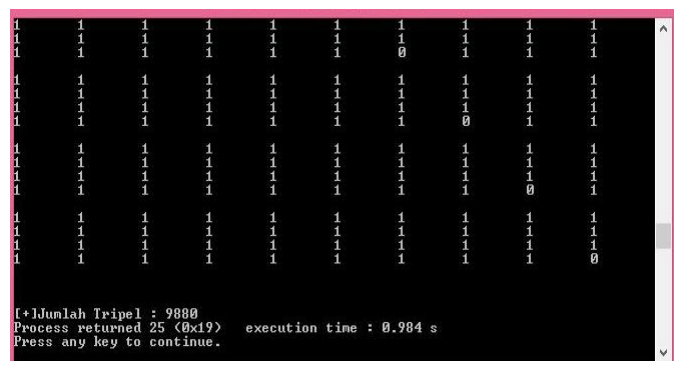

Gambar 6. Contoh Uji Coba Program Model Pertama 


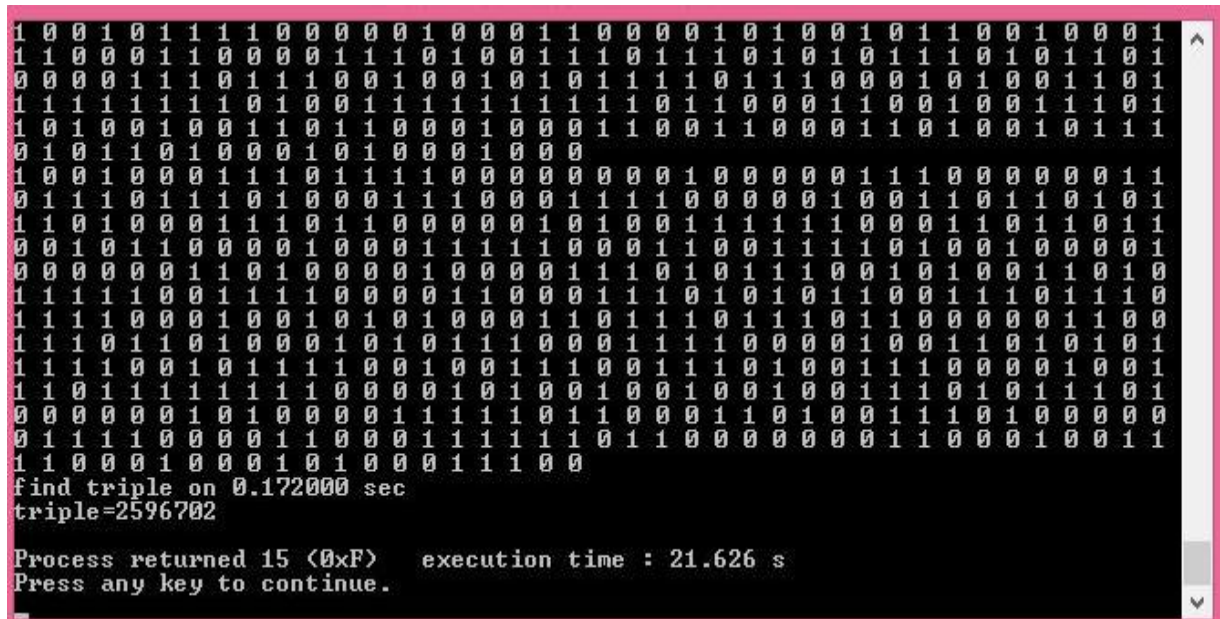

Gambar 7. Contoh Uji Coba Program Model Kedua

\begin{tabular}{|r|r|r|r|r|r|}
\hline Verteks & \multicolumn{1}{|c|}{ X1 } & \multicolumn{1}{|c|}{ Y1 } & \multicolumn{1}{|c|}{ X2 } & \multicolumn{1}{c|}{ Y2 } & \multicolumn{1}{l|}{ Z } \\
\hline 300 & 4455100 & 9.47 & 568821 & 8.81 & 0.03 \\
\hline 400 & 10586800 & 15.78 & 1344279 & 14.85 & 0.09 \\
\hline 500 & 20708500 & 23.76 & 2596702 & 21.63 & 0.17 \\
\hline 600 & 35820200 & 36.02 & 4499984 & 30.14 & 0.31 \\
\hline 700 & 56921900 & 46.79 & 7132116 & 40.47 & 0.45 \\
\hline
\end{tabular}

Gambar 8. Cuplikan Hasil Percobaan Model Program Pertama dan Kedua

1. Keterangan Hasil Analisa Program Model Pertama

Proses analisa menggunakan SPSS untuk mengetahui sejauh mana hubungan ketergantungan antara variabel yang terlibat (Gambar 9 sampai dengan Gambar 11) yaitu : jumlah verteks, waktu penghitungan triple-nya (time find counttriple), jumlah triple, dan waktu yang dibutuhkan untuk menjalankan program hingga diperolah hasilnya (execution time). Fungsi yang dimanfaatkan adalah analisa regresi dan korelasinya. Korelasi utnuk mengetahui tingkat hubungan variabel yang terlibat sedangkan regresi digunakan untuk memprediksi variabel terikat dengan inputan variabel bebas yaitu jumlah verteks (diinputkan pada awal program berjalan).

Model Summary
\begin{tabular}{|l|c|c|c|r|}
\hline \begin{tabular}{l} 
Mode \\
\hline 1
\end{tabular} & $\mathrm{R}$ & $\mathrm{R}$ Square & $\begin{array}{c}\text { Adjusted R } \\
\text { Square }\end{array}$ & $\begin{array}{c}\text { Std. Error of } \\
\text { the Estimate }\end{array}$ \\
\hline 1 & $.992^{2}$ & .984 & .979 & 2.19378 \\
\hline
\end{tabular}
a. Predictors: (Constant), Verteks
b. Dependent Variable: TimeCountTriple1

Gambar 9. Hasil Analisis Pertama Model Program Pertama

\begin{tabular}{|c|c|c|c|c|c|c|}
\hline \multicolumn{7}{|c|}{ Coefficients $^{\mathrm{a}}$} \\
\hline \multirow[b]{2}{*}{ Model } & & \multicolumn{2}{|c|}{ Unstandardized Coefficients } & $\begin{array}{l}\text { Standardized } \\
\text { Coefficients }\end{array}$ & \multirow[b]{2}{*}{$t$} & \multirow[b]{2}{*}{ Sig. } \\
\hline & & B & Std. Error & Beta & & \\
\hline & (Constant) & -21.071 & 3.605 & & -5.845 & .010 \\
\hline & Verteks & .095 & .007 & .992 & 13.675 & .001 \\
\hline
\end{tabular}

a. Dependent Variable: TimeCountTriple1

Gambar 10. Hasil Analisis Kedua Model Program Pertama 


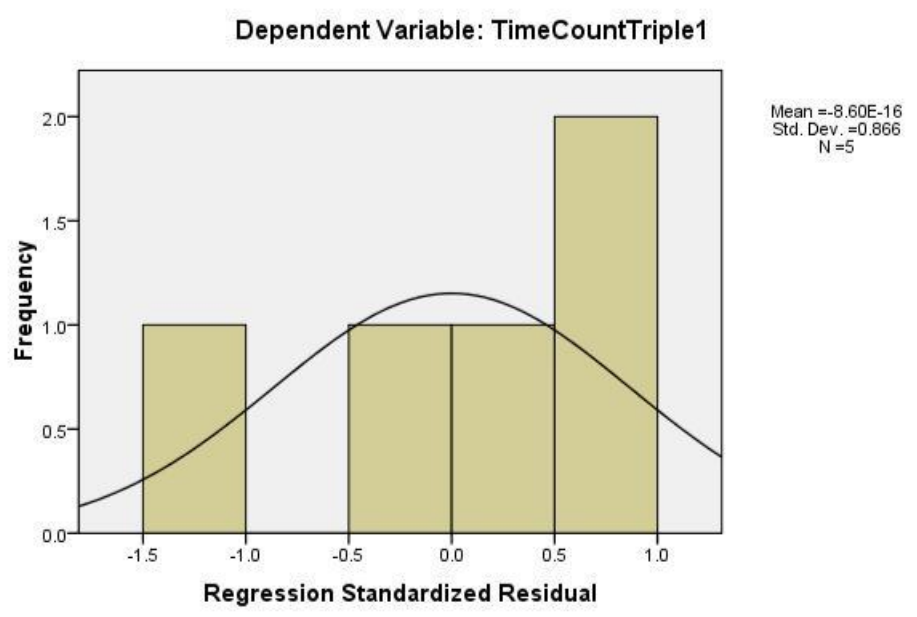

Gambar 11. Hasil Analisis Ketiga Model Program Pertama

Pada analisa pertama dilakukan pada hasil percobaan model program 1 dimana jumlah verteks sebagai variabel bebas (independent) dan waktu yang dibutuhkan untuk melakukan penghitungan jumlah triple-nya sebagai variabel yang dipengaruhi/terikat (dependent). Pada Gambar 9 terlihat nilai koefisien korelasinya sebesar 0,992 mendekati 1 itu bearti hubungan antara kedua variabel tersebut kuat dan nilai R Squared-nya sebesar $98.4 \%$ bahwa jumlah verteks memiliki kontribusi mempengaruhi jumalh waktu eksekusi, sedangkan variabel lainnya hanya sebesar 1,6\%. Standard Error of The Estimate $=2,19$ yang menunjukkan ukuran tingkat kesalahan dalam melakukan prediksi terhadap variabel terikat. Pada Gambar 10 digunakan untuk membentuk taksiran pada garis regresinya, didapatkan hasil sebagai berikut :

$\mathrm{Y}_{1}=\mathrm{a}+\mathrm{bX} \mathrm{X}_{1}$

Dimana :

$\mathrm{Y}_{1} \quad=$ TimeCountTriple

a $\quad$ intercept

$\mathrm{b} \quad=$ slope

$\mathrm{X}_{1} \quad=$ Jumlah verteks yang diinputkan

Hasilnya taksiran garis regresinya adalah $Y_{1}=-21,071+0,095 \mathrm{X}_{1}$

Dari hasil taksiran garis regresi tersebut bisa digunakan untuk memprediksi waktu yang dibutuhkan untuk menghitung jumlah triple apabila diperkirakan jumlah verteksnya dengan nilai tertentu. Misal dilakukan percobaan jumlah inputan verteksnya 2000 maka waktu penghitungan jumlah triple-nya adalah $\mathrm{Y}_{1}=-21,071+$ $0,095 \times 2000=-21,071+180=158,92$ second .

Untuk menguji koefisen garisnya dapat dilihat pada kolom $\mathrm{t}$ dan sig. Hasil pengujian ditemukan nilai t hitung sebesar $-5,845$ dengan sig. $=0,010$ (bandingkan dengan nilai sig. F). Oleh karena nilai sig. $<0,05$ maka Ho $(\beta=0)$ ditolak yang artinya jumlah verteks yang diinputkan berpengaruh positif terhadap waktu yang dibutuhkan untuk menghitung jumlah triple. Positif disitu bearti semakin banyak jumlah verteks yang diinputkan maka semakin lama waktu yang dibutuhkan untuk menghitung jumlah triple-nya. Pada Gambar 11 untuk memperlihatkan bagaimana pendistribusian data yang diperoleh dari hasil percobaan pada program pertama. 
2. Keterangan Hasil Analisa Program Model Kedua

Pada analisa kedua dilakukan pada hasil percobaan model program kedua dimana jumlah verteks sebagai variabel bebas (independent) dan waktu yang dibutuhkan untuk melakukan penghitungan jumlah triple-nya sebagai variabel yang dipengaruhi atau terikat (dependent). Pada Gambar 12 terlihat nilai koefisien korelasinya sebesar 0,994 mendekati 1 itu bearti hubungan antara kedua variabel tersebut kuat dan nilai $\mathrm{R}$ Squared-nya sebesar $98.8 \%$ bahwa jumlah verteks memiliki kontribusi mempengaruhi jumalh waktu eksekusi, sedangkan variabel lainnya hanya sebesar 1,2\%. Standard Error of The Estimate = 1,61 yang menunjukkan ukuran tingkat kesalahan dalam melakukan prediksi terhadap variabel terikat. Pada Gambar 13 digunakan untuk membentuk taksiran pada garis regresinya.

$\mathrm{Y}_{2}=\mathrm{a}+\mathrm{bX} \mathrm{X}_{2}$

Dimana :

$\mathrm{Y}_{2}=$ TimeCountTriple

a $=$ intercept

$\mathrm{b} \quad=$ slope

$\mathrm{X}_{2} \quad=$ Jumlah verteks yang diinputkan

Hasilnya taksiran garis regresinya adalah $Y_{2}=-16,118+0,079 \mathrm{X}_{2}$

Dari hasil taksiran garis regresi tersebut bisa digunakan untuk memprediksi waktu yang dibutuhkan untuk menghitung jumlah triple apabila diperkirakan jumlah verteksnya dengan nilai tertentu. Misal dilakukan percobaan jumlah inputan verteksnya 2000 maka waktu penghitungan jumlag triplenya adalah $\mathrm{Y}_{1}=-16,118+$ $0,079 \times 2000=-16,118+158=141,882$ second .

Untuk menguji koefisen garisnya dapat dilihat pada kolom $\mathrm{t}$ dan sig. Hasil pengujian ditemukan nilai t hitung sebesar $-6,108$ dengan sig. $=0,009$ (bandingkan dengan nilai sig. F). Oleh karena nilai sig. $<0,05$ maka Ho $(\beta=0)$ ditolak yang artinya jumlah verteks yang diinputkan berpengaruh positif terhadap waktu yang dibutuhkan untuk menghitung jumlah triple. Positif disitu bearti semakin banyak jumlah verteks yang diinputkan maka semakin lama waktu yang dibutuhkan untuk menghitung jumlah triple-nya.
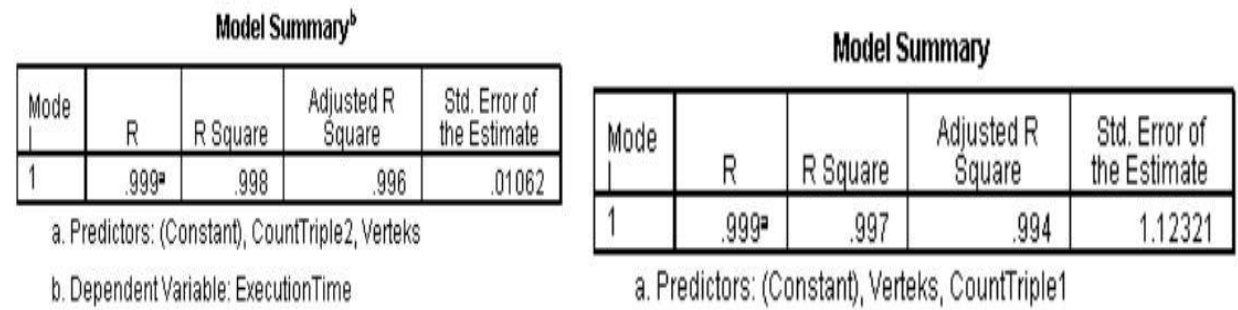

Gambar 12. Hasil Analisis Pertama Model Program Kedua 

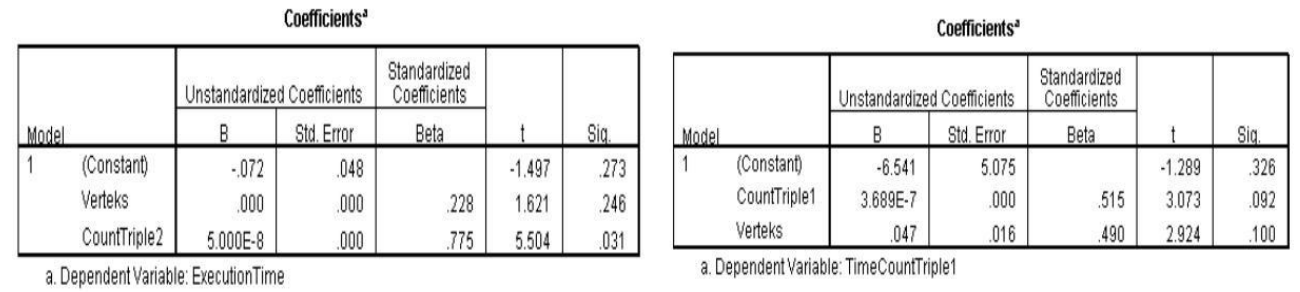

Gambar 13. Hasil Analisis Kedua Model Program Kedua

3. Keterangan Hasil Analisa Program Secara Keseluruhan

Pada analisa keseluruhan, variabel bebas (independent) adalah CountTriple1 dan CountTriple 2 jumlah verteksnya dan waktu yang dibutuhkan untuk melakukan pengerjaan instruksi pada program sebagai variabel yang dipengaruhi atau terikat (dependent) (Gambar 14). Didapatkan hasil bahwa hubungan kedua variabel terikat dan bebasnya adalah positif, artinya waktu eksekusi sangat dipengaruhi oleh jumlah triple yang diproses dan jumlah verteks yang diinputkan. Jadi bisa dikatakan positif atau hubungan searah di sini adalah apabila nilai variabel bebasnya bertambah maka variabel terikatnya ikut bertambah.

CountTriple1

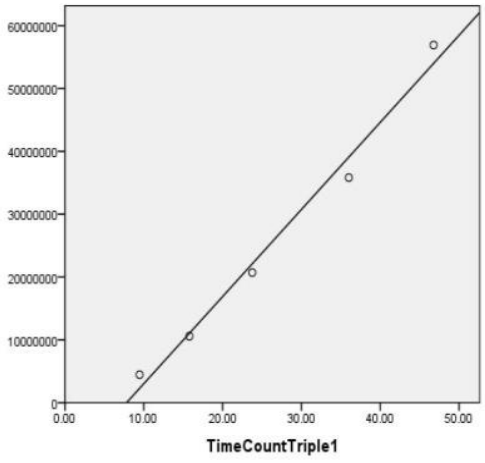

Verteks

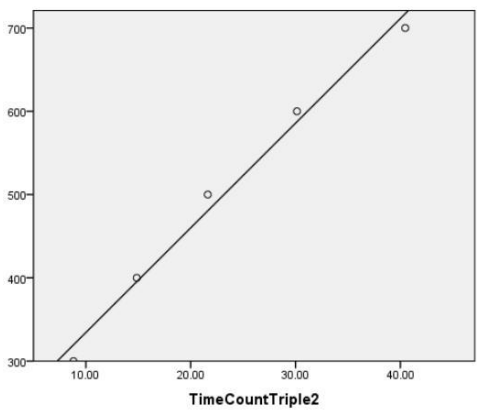

Verteks

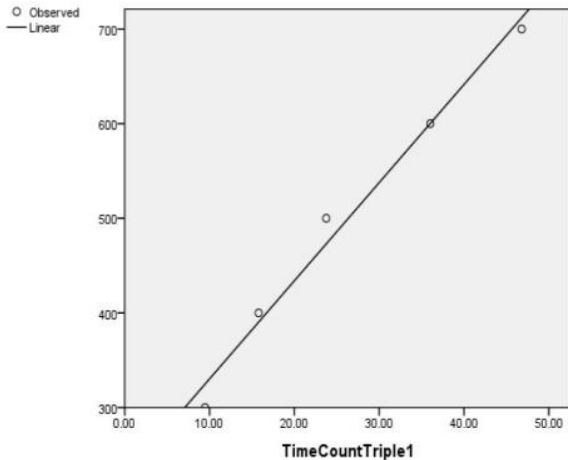

CountTriple2

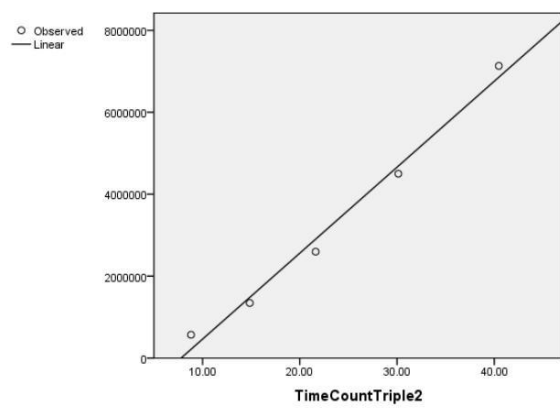

Gambar 14. Hasil Analisis Program Keseluruhan

\section{Kesimpulan}

Berdasarkan uji coba yang dilakukan dapat disimpulkan bahwa kecepatan pemrosesan suatu sistem paralel dipengaruhi oleh jumlah proses dan jumlah verteks. Pada komputer tunggal semakin besar proses maka akan menambahkan sedikit waktu pada pengerjaannya. Begitu pula dengan bertambahnya jumlah verteks mengakibatkan waktu yang diperlukan semakin besar. 


\section{Ucapan Terimakasih}

Penulis mengucapkan terima kasih kepada Sekolah Tinggi Teknologi Adisutjipto Yogyakarta yang telah memberi dukungan finansial terhadap penelitian ini. Juga kepada bagian P3M STTA yang telah membantu tugas dosen untuk melaksanakan salah satu Tridharma perguruan tinggi.

\section{Daftar Pustaka}

[1] Ayuningtyas, A. (2016, November). Pemrosesan Paralel pada Low Pass Filtering Menggunakan Transform Cosinus di MPI (Message Passing Interface). In Conference SENATIK STT Adisutjipto Yogyakarta (Vol. 2, pp. 115-120).

[2] Gebali, F. (2011). Algorithms and Parallel Computing (Vol. 84). John Wiley \& Sons.

[3] Matloff, N. (2011). Programming on Parallel Machines. Retrieved August 23, 2016, from http://heather.cs.ucdavis.edu/ matloff/ParProcBook.pdf.

[4] Quinn, M. J. (2003). Parallel Programming in C with MPI and OpenMP. McGraw-Hill.

[5] Wilkinson, B., \& Allen, M. (2005). Parallel Programming (2nd ed.). Pearson Educational International.

[6] Adji, T. B., \& Nugroho, H. A. (2016, November). Pengaruh Load Balancing Pada Pemrosesan Paralel untuk Kompresi Video. In Conference SENATIK STT Adisutjipto Yogyakarta (Vol. 2, pp. 121-128).

[7] Indrianingsih, Y., Wintolo, H., \& Sari, I. K. (2013, December). Penerapan Grid Computing Untuk Mengkompilasi Program Berbahasa $\mathrm{C} / \mathrm{C}++$. In Conference SENATIK STT Adisutjipto Yogyakarta (Vol. 1, p. 67).

[8] Kelen, W. W., \& Nugraheny, D. (2015). Analisa Pemrosesan Paralel untuk Kompresi dan Dekompresi Data. Compiler, 4(1)

[9] Ngadiyono, N., \& Wintolo, H. (2015). Penerapan Pemrosesan Paralel untuk Menguji Waktu Rendering Design Web dengan Framework terhadap Processor melalui Lan, Router dan Ekstranet. Compiler, 4(1). 